\title{
Fetal life malnutrition was not reflected in the relative abundances of adiponectin and leptin mRNAs in adipose tissue in male mink kits at 9.5 weeks of age
}

\author{
Connie F. Matthiesen ${ }^{1}$ and Anne-Helene Tauson ${ }^{1,2^{*}}$
}

From Animal Obesity - causes, consequences and comparative aspects

Uppsala, Sweden. 14-16 June 2015

\begin{abstract}
Background: Malnutrition in fetal life and during suckling have in some animal studies resulted in adaptive changes related to the fat and glucose metabolism, which in the long term might predispose the offspring for metabolic disorders such as obesity later in life. The objective was to study the effect of fetal life malnutrition in male mink on the gene expression of leptin and adiponectin in different adipose tissue sites.

Results: Thirty-two male mink, strict carnivore species, exposed to low (FL) or adequate (FA) protein provision the last $16.3 \pm 1.8$ days of fetal life and randomly assigned to a low (LP) or adequate (AP) protein diet from 7 to 9.5 weeks of age were used. Adipose tissues (subcutaneous, perirenal and mesenteric) were analyzed using qPCR. Fetal life or postweaning protein provision did not affect the relative abundances of leptin and adiponectin mRNAs in adipose tissue at 9.5 weeks of age. Relative abundances of leptin and adiponectin mRNAs were different between adipose tissue sites and were significantly higher in subcutaneous than in perirenal and mesenteric tissues.

Conclusion: Fetal life protein malnutrition in male mink, did not result in adaptive changes in the gene expression of leptin and adiponectin mRNAs in adipose tissue at 9.5 weeks of age as found in rodents. However, both leptin and adiponectin mRNAs were significantly differently expressed between tissue sites.
\end{abstract}

Keywords: Fetal life malnutrition, Adipose tissue, Gene expression, Carnivores

\section{Findings}

Malnutrition in utero can result in adaptive changes in the glucose and fat metabolism and may lead to increased fat deposition later in life. Exposing mink, a strict carnivore, to low protein provision in utero has resulted in lower birth weights $[1,2]$ and changes in the gene expression of fructose-1,6-biphosphatase, pyruvate kinase,

\footnotetext{
*Correspondence: aht@sund.ku.dk

${ }^{1}$ Department of Veterinary Clinical and Animal Sciences, Faculty of Health and Medical Sciences, University of Copenhagen, Grønnegardsvej 3, 1870 Frederiksberg C, Denmark

Full list of author information is available at the end of the article
}

fatty acid synthase and carnitine palmitoyl transferase, enzymes important for glucose $[1,3,4]$ and fat homeostasis [5]. Present study investigated if the relative abundances of leptin and adiponectin mRNAs, both playing a key role in lipid and energy metabolism, were affected post-weaning by fetal life malnourishment.

Thirty-two male mink kits exposed to low (FL-14 \% of metabolizable energy from protein-14P) or adequate (FA-29P) protein provision the last $16.3 \pm 1.8$ days of fetal life were used. The FL kits had significantly lower birth weight (10.3 g vs. $11.3 \mathrm{~g} ; P=0.004$ [1]) than FA kits. An adequate protein provision was given from birth to 
weaning. At weaning, FL and FA males were randomly assigned to a low (LP-18P) or adequate (AP-32P) protein diet from 7 to 9.5 weeks of age giving four treatment groups (i.e. FA-AP, FA-LP, FL-AP, FL-LP). Dietary details are provided elsewhere $[1,4]$.

The experimental procedures followed the Danish National Legislation (license 2005/561-994), and was performed at the University of Copenhagen, Denmark.

At 9.5 weeks of age the males were anaesthetized by an intramuscular injection of $10.0 \mathrm{mg} / \mathrm{kg} \mathrm{BW}$ Ketaminol and $2.0 \mathrm{mg} / \mathrm{kg}$ BW Narcoxyl (InterVet, Skovlunde, Denmark) and euthanized by excision of the heart. Tissues were collected, flash frozen and stored at $-80{ }^{\circ} \mathrm{C}$ until analyses. The relative abundance of mRNA was estimated by quantitative real-time PCR using SYBR Green-I-detection and LightCycler 480 real-time PCR system (Roche Diagnostics, Copenhagen, Denmark). The tissue preparation, RNA extraction and RT-PCR program is described elsewhere [4]. The RT-PCR primers are listed in Table 1, and $18 \mathrm{~S}$ rRNA was used as reference gene.

The relative abundance of leptin mRNA was not affected by FL protein provision which corresponded with the plasma leptin concentration and chemical body composition [4]. These results were supported by findings of the relative abundance of leptin mRNA in adult female mink [3] and the body composition of adult male mink [6] both protein malnourished in utero. This was in contrast to findings in male mice, protein malnourished in utero and during suckling, in which a lower body weight, circulating plasma leptin and abundance of leptin mRNA were found after weaning [7]. The relative abundance of adiponectin mRNA was not affected by fetal life or post-weaning protein provision similar to findings in rats exposed to protein restriction in fetal life and during suckling. However, if the rat offspring were fed a high energy diet post-weaning, the expression was significantly reduced [8]. The relative abundances of adiponectin and leptin mRNAs were both significantly different between adipose tissue sites (Fig. 1), having the highest

\section{Table 1 Gene specific RT-PCR primers}

\begin{tabular}{|c|c|c|c|}
\hline Gene & Genebank & Sequence $\left(5^{\prime}-3^{\prime}\right)$ & Length (bp) \\
\hline Adiponectin & AB115956 & $\begin{array}{l}\text { 5'TGGGATTGGAGA } \\
\text { GTCGGGT3' } \\
\text { 5'ACTGGTCGTAGGTGAA } \\
\text { GAGCA3' }\end{array}$ & 216 \\
\hline Leptin & AB041360 & $\begin{array}{l}\text { 5'TAGCCACATCCCTTTGAA } \\
\text { GCA3' } \\
\text { 5'ATTCACATCCCTCACCTC } \\
\text { CTG3' }\end{array}$ & 243 \\
\hline 18S rRNA & M10098.1 & $\begin{array}{l}\text { 5'CGAGCCGCCTGGATACC }{ }^{\prime} \\
\text { 5'CCTCAGTTCCGAAAAC } \\
\text { CAACAA3' }\end{array}$ & 76 \\
\hline
\end{tabular}

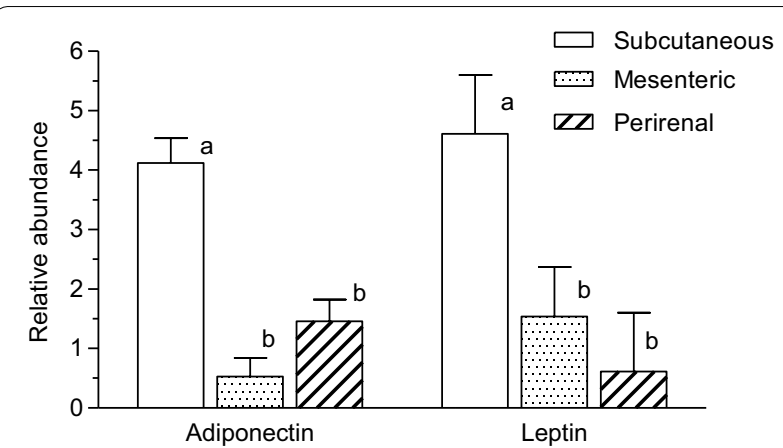

Fig. 1 The relative abundances of leptin and adiponectin mRNAs. The relative abundances of adiponectin and leptin mRNAs normalized to $18 \mathrm{~s}$ rRNA in subcutaneous, mesenteric and perirenal adipose tissues from male mink kits exposed to fetal life low or adequate protein provision and fed a low or adequate protein diet post-weaning from 7 to 9.5 weeks of age

expression in subcutaneous tissue. These differences were similar to findings in humans where the expression of leptin [9] and adiponectin mRNA were the highest in subcutaneous tissue $[10,11]$. However, studies in lean rats have reported a higher abundance of adiponectin in visceral than in subcutaneous fat, whereas it was conversely in zucker diabetic rats [12].

In conclusion, fetal life protein malnourishment was not reflected in the abundance of leptin and adiponectin mRNAs similar to other findings in adult mink but in contrast to some findings in rodents, probably due to species differences and length of exposure to malnourishment. Both leptin and adiponectin mRNAs were differently expressed between tissue sites as found in other species.

\section{Authors' contributions}

CFM performed the study, q-PCR, statistical analysis and drafted the manuscript. AHT designed the study, helped to retrieve the tissue, the statistical analyses and drafted the manuscript. Both authors read and approved the final manuscript.

\section{Author details}

${ }^{1}$ Department of Veterinary Clinical and Animal Sciences, Faculty of Health and Medical Sciences, University of Copenhagen, Grønnegardsvej 3, 1870 Frederiksberg C, Denmark. ${ }^{2}$ Department of Animal Nutrition and Management, Swedish University of Agricultural Sciences, Ulls väg 26, Uppsala, Sweden.

\section{Acknowledgements}

Thanks to Merethe Stubgaard for helping performing the experiment and to Anne Friis for helping performing the q-PCR. This work was supported by the Danish Food Industry Agency of the Ministry of Food, Agriculture and Fisheries [Grant number 5414114.95.304].

\section{Competing interests}

Both authors declare that they have no competing interests.

\section{Declaration}

Publication charges for this article were funded by the research platform Future Animal Health and Welfare at the Swedish University of Agricultural Sciences. 


\section{About this supplement}

This article has been published as part of Acta Veterinaria Scandinavica Volume 58 Supplement 1, 2016: Animal Obesity_causes, consequences and comparative aspects: current research. The full contents of the supplement are available online at http://actavetscand.biomedcentral.com/articles/ supplements/volume-58-supplement-1.

\section{Availability of data and materials}

All data generated or analysed during this study are available from the corresponding author on reasonable request.

\section{Ethics approval and consent to participate}

The experimental procedures followed the guidelines of the European Convention for the Protection of Vertebrate Animals used for Experimental and Other Scientific Purposes as well as Danish national legislation. All experimental procedures were approved by The Animal Experiment Inspectorate, Denmark.

\section{Published: 20 October 2016}

\section{References}

1. Matthiesen CF, Blache D, Thomsen PD, Hansen NE, Tauson AH. Effect of late gestation low protein supply to mink (Mustela vison) dams on reproductive performance and metabolism of dam and offspring. Arch Anim Nutr. 2010;64:56-76.

2. Vesterdorf K, Harrison A, Matthiesen CF, Tauson AH. Effects of protein restriction in utero on the metabolism of mink dams (Neovison vison) and on mink kit survival as well as on postnatal growth. Open J Anim Sci. 2012;2:19-31.

3. Matthiesen CF, Blache D, Thomsen PD, Tauson AH. Feeding mink (Neovison vison) a protein restricted diet during pregnancy induces higher birth weight and altered hepatic gene expression in the $\mathrm{F}_{2}$ offspring. $\mathrm{Br} J$ Nutr. 2010;104:544-53.
4. Matthiesen CF, Blache D, Thomsen PD, Tauson AH. Foetal life protein restriction in male mink (Neovison vison) kits lowers post-weaning protein oxidation and the relative abundance of hepatic fructose-1,6-bisphosphatase mRNA. Animal. 2012;6:50-60.

5. Matthiesen CF, Casañas MAA, Tauson AH. Foetal life protein provision of mink (Neovison vison) changes the relative mRNA abundance of some hepatic enzymes regulating fat metabolism. Arch Anim Nutr. 2014;68:159-69.

6. Vesterdorf K, Blache D, Harrison A, Matthiesen CF, Tauson AH. Low protein provision during the first year of life, but not during foetal life, affects metabolic traits, organ mass development and growth in male mink (Neovison vison). J Anim Physiol Anm Nutr. 2014;98:357-72.

7. Jousse C, Parry L, Lambert-Langlais S, Maurin AC, Averous J, Bruhat A, et al. Perinatal undernutrition affects the methylation and expression of the leptin gene in adults: implication for the understanding of metabolic syndrome. FASEB J. 2011;25:3271-8.

8. Bieswal F, Ahn MT, Reusens B, Holvoet P, Raes M, Rees WD, Remacle C. The Importance of catch-up growth after early malnutrition for the programming of obesity in male rat. Obes Res. 2006;14:1330-43.

9. Schoof E, Stuppy A, Harig F, Carbon R, Horbach T, Stöhr W, et al. Comparison of leptin gene expression in different adipose tissues in children and adults. Eur J Endocrinol. 2004;150:579-84.

10. Iglesias MJ, Eira S, Piñeiro R, López-Otero D, Gallego R, Farnández AL, et al. Gender differences in adiponectin and leptin expression in epicardial and subcutaneous adipose tissue. Findings in patients undergoing cardiac surgery. Rev Esp Cardiol. 2006;12:1252-60.

11. Montague CT, Prins J, Sanders L, Digby JE, O'rahilly S. Depot- and sexspecific differences in human leptin mRNA expression: implications for the control of regional fat distribution. Diabetes. 1997;46:342-7.

12. Altomonte J, Harbaran S, Richter A, Dong H. Fat depot-specific expression of adiponectin is impaired in Zucker fatty rats. Metabolism. 2003;52:958-63.

\section{Submit your next manuscript to BioMed Central and we will help you at every step:}

- We accept pre-submission inquiries

- Our selector tool helps you to find the most relevant journal

- We provide round the clock customer support

- Convenient online submission

- Thorough peer review

- Inclusion in PubMed and all major indexing services

- Maximum visibility for your research

Submit your manuscript at www.biomedcentral.com/submit
(O) Biomed Central 